\title{
Reputational Risk and Corporate Social Responsibility: How to Make CSR Policies Attractive to Productive Corporations ${ }^{1}$
}

\author{
Reputational Risk and Corporate Social Responsibility: How to Make CSR \\ Policies Attractive to Productive Corporations
}

David Augusto Echeverry Botero ${ }^{2}$

Fecha de recepción: 2 de febrero de 2015

Fecha de aprobación: 20 de abril de 2015

\begin{abstract}
In traditional economic theories, corporation main task is only to generate profits for the investors. However, in modern global economies, some companies have more money and power than many countries, many activist sectors and governments began to look closely at the role of those businesses in order to prevent abuses and environmental harm, and such an audit would create reputational risk that can strongly affect companies' profits.
\end{abstract}

Although some corporations undervalue Corporate Social Responsibility (CSR) policies, these could be a way to mitigate reputational risks, generate competitive advantages and new forms of competition, increase the value of the stocks and shares, and be the key to sustainable business.

1 This article derived from a research developed at the University of Melbourne, where the author was pursuing a master's degree in Commercial law, as part of the Corporate Social Responsibility class. The research was conducted between 2010 and 2012 .

2 Lawyer graduated from the Pontificia Universidad Javeriana who holds a master's degree in Economic law, earned at the same university, and a master's in Commercial Law (LL.M) from the University of Melbourne. Professor at the Masters' program in Economic Law, Pontificia Universidad Javeriana, in the fields of scientific research and research seminars. He also serves as director of research projects on the expertise of Contract Law of the Universidad Santo Tomás, and is a professor of General Business Law, and European Law and economic integration classes at the Universidad Politécnico Grancolombiano. Email: davidaugustoecheverry@yahoo.es 
Keywords: Advertising, competition, corporate social responsibility, corporations, media revolution, profit maximization, reputational risk, transaction cost.

\section{RESUMEN}

En la teoría económica tradicional, se asumía que la tarea principal y exclusiva las corporaciones o sociedades era generar beneficios para los inversionistas. Sin embargo, en las economías modernas, enmarcadas en una economía global, algunas empresas tienen más dinero y poder que muchos países. Entonces, con el fin de prevenir los abusos y los daños al medio ambiente, muchos sectores de activistas y los gobiernos están comenzando a examinar el papel de estas organizaciones. Este tipo de fiscalización genera un riesgo reputacional que puede afectar gravemente las ganancias de las empresas.

En este orden de ideas, las políticas de Responsabilidad Social Corporativa (RSC), a pesar de no ser apreciadas por algunas empresas, podrían ser una forma de mitigar esos riesgos, generar ventajas competitivas y nuevas formas de competencia, aumentar el valor de las acciones y participaciones y ser la clave para un negocio sostenible.

Palabras clave: competencia, corporaciones, costos de transacción, maximización del beneficio, publicidad, responsabilidad social corporativa, revolución de los medios, riesgo reputacional.

\section{INTRODUCTION}

Convincing enterprises to apply corporate social responsibility policies or to encourage government to impose them is not an easy task. Some experts, such as Karnani (2010), contend that corporate social responsibility (abbreviated CSR, hereafter) has no practical application because, in some scenarios, the generation of profits is in conflict with social welfare. This dichotomy makes some firms take distance from their corporate social responsibilities and behave only under a desire 
to maximize profits; sometimes, this position counteracts social goals and entails harming the environment (Karnani, 2010).

CSR policies can cause reputational risks to companies under competitive markets. In brand-oriented companies, CSR policies may decrease profits for the company, reduce company's worth, and compromise business viability in the medium-term and in the long-term (see McBarnet, 2009, for an analysis of the Global Survey of Business Executives). However, "there is also mounting of evidence that companies that integrate and embed CSR principles throughout their operations tend to be better run and therefore present a less risky investment" (Rayner, 2004, p. 40). Similarly, implementing good CSR practices in a company can lower the reputational risks faced. By doing so, companies obtain a competitive advantage, increase the value of intangible assets and protect against a drop in share prices.

To make a sound case for adopting CSR, this paper tackles first challenges in determining and applying CSR policies in some market production systems and scenarios. Second, it defines reputational risk, and describes which variables are affected in the long-term when a brand-oriented company suffers a reputation harm. Finally, it concludes arguing that, when companies are aware of their reputational risk, CSR policies beyond the law become an outstanding tool to reduce reputational risk and to increase business competitiveness.

\section{Corporations and Corporate Social Responsibility}

\section{What is Corporate Social Responsibility?}

It is not an easy task to define what corporate social responsibility is. Still, it is important to begin with a definition to understand the scope, limits, and context in which it would be possible to talk about a responsible corporation. In the World Business Council for Sustainable Development, corporate social responsibility was defined as "the commitment of business to contribute to sustainable economic development, working with employees, their families, the local community and 
society at large to improve their quality of life" (Rayner, 2004, p. 39). According to this definition, CSR scope of action is very wide; however, it remains unclear what CSR is.

The National Association of Pension Funds provides a helpful clarification: CSR covers a wide spectrum of interdependent areas (Rayner, 2003). Broadly, CSR comprises a company's ethical behaviour, the environmental impacts of a company's operations and products, interactions between the company and its staff, customers, suppliers, community, and any other key stakeholders. CSR also encompasses the principle of sustainability. Thus, it will be expected that a company's operations and products result in maintaining and, if possible, enhancing, the quality of the environment and society (Rayner, 2003).

From the previous clarification and the initial definition, we can draw key deductions that will provide us with a complete understanding of CSR. First, any company should act in a proper and ethical way in different scenarios. Second, companies, and their products, may be held responsible for the environment. Third, the perspectives of workers and, most importantly, the stakeholders to whom the corporation is responsible are fundamental. Fourth, the sustainability principles are to be followed: Corporations must not focus on short-term profits, but rather on creating and implementing medium-term and long-term responsible policies. Fifth, corporations are a part of the society that play a role on improving, or at least preserving, the environment and social standards. "CSR is not philanthropy, contributing gifts from profits, but involves the exercise of social responsibility in how profits are made" (Rayner, 2004, p. 29).

CSR is not limited to social and environmental issues, but influences the whole business operation. Aspects as taxes and accountability, inter alia crucial areas of the business, are included after cases like Nike, GM, and Enron (Rayner, 2004).

According to the definition and the clarification, corporations are starting to be seen as citizens that are part of the society. In this context, the corporations are an active agent who has the responsibility not only to generate profits to its shareholders but also, through the core of their business, to contribute to the society and the 
environment. "In a nutshell, CSR is how the company relates to its stakeholders from a sustainable and environmentally aware perspective” (Mulvey, 2008, p. 65).

The actual markets and the society changes demand that the business have a social acceptance (Mele, 2008). The viability of a corporation in the long-term is intimately related to social development and to how a corporation relates with its stakeholders. The long-term policies in a competitive and good company must have in mind not only their shareholders but also all the people who are related with the company or can be affected by it.

"A successful business firm needs much more than self-interest and concern for profits. It requires trust, a sense of loyalty, and good relationships with all stakeholders and, as a consequence, an enduring cooperation among those who are involved in or are interdependent with the firm". (Mele, 2008, p. 61)

The previous premise is the base of the stakeholder theory. This theory includes all the individuals that can receive a benefit from the corporation or harm from the business actions (Mele, 2008). Hence, while doing business, corporate responsibility is to act well towards anyone who has a 'stake' in the company or, in other words, towards anyone who is touched by the corporation or who has an interest in it-its behaviour must be according to the social accepted principles of those stakeholders (Mele, 2008).

However, the definition and the clarification provide a useful explanation: there is an ongoing debate about the understanding of and the real scope of CSR.

\section{Corporate Structure, Profit Maximization and CSR}

The focus on profit, which was the most important in the neoclassical economic theory, changed to a wider perspective. Now, the goal of a corporation is not merely to maximize profits attributable to the shareholders in the short-term. The corporation also needs to generate wealth and better conditions for all the stakeholders. All this without doing, or doing the less possible, harm to the environment. In this way, 
the viability of the enterprise in the medium-term and long-term is ensured (Mele, 2008).

While a company abandons the old view that a business goal is only to maximize profits, it adopts a higher ethical value because "it takes into consideration stakeholder rights and their legitimate interest, and not only what is strictly required by the law in manager-stakeholder relations" (Mele, 2008, p. 66). This process results in a CSR above the law: The corporation, searching for a better development in the market, assumes higher responsibilities than those imposed by the law (Mele, 2008).

In summary, this perspective contributes to increase corporate social responsibility without imposing big economic loads to the corporation, which would represent a disadvantage for them in a competitive market.

\subsection{Corporate structure}

In order to understand what Corporate Social Responsibility is, it is important to define first what a corporation is. Then, based on its constituent elements, analyse which kind of responsibility they can assume. According to Armour, Hansmaan and Kraakman (2009), a corporation can be defined by its structural elements: (1) legal personality, (2) limited liability, (3) transferable shares, (4) centralized management under a board structure, and (5) shared ownership by contributors of capital.

As any other natural person, a legal person, different to the shareholders, has rights and duties. Therefore, the legal person has a will, which is expressed through the decisions made by the board of directors.

To acquire legal personality, a corporation should have separate patrimony. Separate patrimony "involves the demarcation of a pool of assets owned, singly or jointly, by the firm's owner (the shareholders), and of which the firm in itself, acting through its designated managers, is viewed in law as being the owner" (Armour, Hansmaan, \& Kraakman, 2009, p. 6). This division between the corporate patrimony and shareholders' patrimony generates a limited liability. The liability of the shareholders goes up to, but never exceeds, the amount given to the corporation. 
In a corporation, a unique phenomenon occurs. Even if the shareholders are the owners of the corporation, they usually do not have the power to make specific decisions. Their biggest prerogatives are to change the board of directors if they disagree with some decisions that the directors have taken, or to sell their shares and take their capital to another investment (Armour et al., 2009).

This phenomenon varies slightly depending on the legal system where the corporation is created (e.g. in Colombia, the shareholders have other kind of prerogatives). However, in general, the decision-making power in corporations is given to the board of directors. That organism is responsible for the corporations. The decisions of the board of directors determine corporate responsibilities. According to them, the main responsibility is to generate wealth to their shareholders (Armour et al., 2009).

\subsection{Profit maximization and CSR}

The idea that a corporation has a social responsibility has not been easily accepted.
"Only people can have responsibilities. A corporation is an artificial person and in this sense may have artificial responsibilities, but "business" as a whole cannot be said to have responsibilities, even in this vague sense. The first step toward clarity in examining the doctrine of the social responsibility of business is to ask precisely what it implies for whom" (Friedman, 1970, p. 1).

In terms of corporations and their views of social responsibility, according to Mele (2008), there are three possible groups:

I. those who believe that corporations are an artificial entity that has only the responsibility to generate profits to their shareholders.

II. those who consider that a corporation, even if it is not a natural person, must act according to the morals, and 
III. those who believe that a corporations, as citizens, have the same duties of a citizen in a society.

The most prominent exponent of the first group is Milton Friedman. According to Friedman (1970), the only responsibility a corporation and its directors is to generate "as much money as possible" (p.1) for the shareholders. Because of that reason, if directors work with a different idea in mind, they would be acting against the interest of their employers.

From that perspective, to achieve the social goals is the task of the government, not of private business. CSR may be seeing "as management going beyond its [directors] legal powers (acting 'ultra vires') or even in breaching its fiduciary duty to the owners" (McBarnet, 2007, p. 23). Consequently, the directors see CSR as a breach of the law.

That perspective has been criticized. Critics contend that if the only responsibility of a corporation is to generate profits to the shareholders and to maximize profits, the corporation is an externalizing machine, whose business takes advantage of people and the environment and harms them (Bakan, 2004). In that context, "all the bad things that happen to people and the environment as a result of corporations' relentless and legally compelled pursuit of self -interest are thus neatly categorized by economist as externalities- literally, other people's problems" (Bakan, 2004, p. 61).

Following the notion of the invisible hand proposed by Adam Smith, "companies acting in their own self-interest will lead to a socially optimal outcome" (Karnani, 2011, p. 70). Smith understood that the economy, as a living organism, would reach a social optimal state without intervention; provided that the economy is based on perfect markets and that every market is efficient (Karnani, 2011). However, to reach a social optimum without some CSR practices is unlikely because there is not a perfect market. "Market failures occur due to three causes: externalities, asymmetric information, and market power" (Karnani, 2011, p. 73).

Focusing on profit generation could generate a negative incentive to directors since they, in the pursuit of profits, will be willing to take decisions that can cause harm to the environment-negative externality-, to the stakeholders or to the corporation 
itself in the medium-term and long-term. One example of this kind of harmful behaviour is found in the Anderson v. General Motors case:

\begin{abstract}
"After a lengthy trial the jury found that GM [General Motors] had dangerously positioned the fuel tank to save costs, and Los Angeles Superior Court Judge Ernest G. Williams later upheld its verdict (thought he reduced the damages). "The Court finds that clear and convincing evidence demonstrated that defendants' fuel tank was placed behind the axle on automobiles of the make and model here in order to maximize profits - to the disregard of public safety”. (Bakan, 2004, p. 62)
\end{abstract}

This behaviour not only harmed the company, because of the fine that it received, but also generated the perception in the stakeholders that General Motors is a bad company. This reputational damage will produce a big reduction in its sales because nobody is going to buy a car knowing that it can kill you.

Nevertheless, the scandals that occurred in the U.S. between 2001 and 2002 showed that profitability indicators could be easily manipulated by "creative accountants". Furthermore, losing reliability might become an indicator of good corporate performance (Rayner, 2003).

In contrast with the first position, represented by Friedman, others wonder if it is possible to do well by doing good. They query whether it is feasible to maximize profits while being corporate social responsible. Those who answer affirmatively to the previous questions take one of the last two stances on corporate social responsibility mentioned earlier. They believe that corporations must act ethically; directors cannot focus only on profit maximization.

Directors' perspectives of the correct system of production and of their responsibilities towards the society, specifically towards stakeholders, are starting to change.

"In a survey in December 2005, by management consultants McKinsey, only 6 per cent of the 4,283 executives surveyed worldwide agreed with the Milton Friedman Line that the sole purpose of business was to produce high returns 
for shareholders; 84 per cent thought high returns had to be balanced with contributions to the broader public good.” (McBarnet, 2007, p. 33)

In current markets, corporate agents are huge and, in some cases, more powerful than a country; hence, a bigger corporate responsibility is required (Mele, 2008, p. 49).

"According to the 'do well by doing good' (DWDG) proposition, firms have a corporate social responsibility (CSR) to achieve some larger social goals, and can do so without a financial sacrifice. The most important driver of corporate interest in CSR is the argument that corporate virtue delivers financial rewards." (Karnani, 2011, p. 69)

Directors are not usually predators: they neither do everything for money nor are comfortable destroying the resources that their business will need in the future. Therefore, they are concerned with corporate reputation and their individual reputation. They are aware of the fact that a bad decision could affect their business and their inner circles. For instance, the directors of General Motors will be in disgrace with family, friends, colleagues and subordinates because, based merely on a desire to make profits, GM directors made decisions that put many lives at risk.

With reference to interests, it is possible to delineate two zones: zone of opportunity and zone of disaster. In the first one, "the interest of private companies and of the society are aligned together; there is an opportunity to make choices that lead to improving both profits and social welfare" (Karnani, 2011, p. 73). In the second zone, however, "there is a fundamental conflict between private profits and public interest. Free markets operate at the private optimum and will not produce a socially desirable outcome" (Karnani, 2011, p. 74). The social and private interests are not aligned. In this last scenario, the voluntary application of CSR policies is unfeasible and legal intervention is necessary to protect the social interest.

In a zone of disaster and under legal pressures to maximize profits, the managers of the company are penalizing the shareholders. Thus, "companies talk a lot about CSR but do very little [...]. In a survey on CSR, the magazine The Economist concluded 
that, for most public companies, 'CSR is little more than a cosmetic treatment."' (Karnani, 2011, p. 77).

Indeed, in an economic system of competitive markets, making profits is not always easy. In this context, CSR can be a competitive advantage or a disadvantage for a company depending on the market and on where the business is located, which can determine what and how policies are implemented (Karnani, 2011).

Individuals' behaviour varies according to their different roles and contexts. As investors, they desire to maximize their profits but, as members of the community, they want to fulfil their social obligations. Therefore, corporations continue maximizing profits, while their shareholders donate and participate in charity or other social activities. From their perspective, all their objectives can be achieved by adding both roles and contexts.

Similarly, Bill Gates has given away the bulk of his fortune to charity through the Gates Foundation; Gates clearly does good. Microsoft, on the other hand, has often been criticized for unethical behaviour ranging from labor to intellectual property to anticompetitive prices. The company has been the subject of numerous lawsuits by several governments for unlawful monopolistic practices. Without implying that these allegations are true, Microsoft is certainly not a role model for CSR. Again, Microsoft does well; Gates does good. (Karnani, 2011, p. 78)

\subsection{Should CSR policies be compulsory?}

As said before, when profit maximization conflicts with the implementation of CSR policies, it is not easy to convince the directors to manage the corporation according to those principles. Because of that reason, there is an ongoing debate about the obligatory nature of CSR policies.

From my point of view, this particular issue determines the paper of the CSR beyond, through or above the law. "The adoption of CSR policies by business has taken place in a very specific context. If CSR is self-governance by business, it is nonetheless self- 
governance that has received a very firm push from external social and market forces" (McBarnet, 2007, p. 12). Nevertheless, as explained in the first part of this paper, CSR encompasses more than the mere corporate governance.

Firstly, although, in theory, perfect markets will reach social welfare without any intervention, in practice, markets are imperfect. In consequence, some intervention is needed. It is not probable to apply CSR and increase profits when profits and social welfare is a zero-sum game. Thus, either the law makes market agents act according to the social goals or society generates other kind of methods to compel corporations to make market players behave according to social objectives.

Although "government is the ultimate solution for responding to market failures" (McBarnet, 2007, p. 14), another problem arises from economic intervention. The regulation over a market imposing corporate social responsibilities obligations or duties to the corporations can also be a disappointment (McBarnet, 2007).

Considering that strong corporations have their strong lobby structures and that the parliament are formed by individuals of different professions who are not always experts in market regulation, a law to make CSR compulsory could not solve the problem; instead, it could create a worse situation. In a government vs. market failure context, regulation of CSR is not the only answer and it must be seen with extreme caution (McBarnet, 2007).

Secondly, CSR above the law, using self-regulation, also has its issues (McBarnet, 2007). In some cases, self-regulation is used to prevent or to avoid government regulation, but it could potentially eliminate the whole idea of achieving better social practices in the companies (McBarnet, 2007). Government should not pass its obligation for regulation entirely to corporations. Voluntarism might imply that, when maximization of profits and social welfare are opposite, internal codes or rules of conduct are violated (McBarnet, 2007).

Finally, "another source of constrains on free markets to increase public welfare and achieve some positive social goals is activism by civil society (organizations such as consumer movements, non-governmental organizations, and charitable 
foundations)" (McBarnet, 2007, p. 81). The generation of a social capital in a society provides the best "watch dog" for bad market and social practices (Caro, 2006).

Each of the three ways to make corporations adopt CSR measures has a key limitation: they work very well just in brand-oriented companies. Despite of all, it is hard to find a current company that is not concerned with its image or brand(s). The application of CSR policies is intimately related to the importance that the corporation gives to its reputation and brand: When a company acts in an improper manner, its reputation and brands will be directly affected.

\subsection{CSR beyond the law}

The increase in the importance of the intangible assets, such as reputation, stocks, intellectual property, good will etc., has created a new vulnerability for the firms. In a competitive market, this vulnerability could control corporate behaviour beyond what the law requires. That control may occur because companies know that the value of profits and firms could be affected by corporate actions or behaviours. If the behaviour is improper, it will represent losses in the intangible assets (McBarnet, 2007). For example, "Professor Baruch Lev, from the Stern School of Business at New York University, estimated that in 1998 US industrial companies invested as much in intangible assets such as R\&D and training as they did in physical plant and equipment"(McBarnet, 2007, p. 14)

The dichotomy between profits and social responsibility has caused that the voluntary adoption of CSR policies by the corporation is often a reaction to social and/or governmental pressure, derived from the negative effects of a corporate policy (See McBarnet, 2007, for an analysis of Nike and Shell cases).

As demonstrated by the Nike case, brand-oriented corporations are especially vulnerable to bad publicity, and, as a result, their sells could be harmed by it. Even if a corporation does not directly breaks legal or social rules, an infraction made by someone associated to the corporation can have negative repercussions. For instance, in the Nike case, the breach of the labour laws was done by a Nike's subcontractor but it affected Nike, as a corporation (McBarnet, 2007). 
Therefore, "companies cannot afford to risk their reputation coming under challenge. According to research by insurance company Aon, the top 2000 private - and publicsector organizations regard damage to reputation as their biggest risk"(McBarnet, 2007, p. 17).

Thus, CSR becomes a competitive advantage: it reduces reputational risk. Consumers, workers and investors are starting, to prefer those companies and products that have a good reputation over those from the companies that have bad reputations. They select the former companies and products even if their prices are higher, so this is a trade-off (McBarnet, 2007). Nowadays, consumers are buying products from "good" corporations, investors are investing in those corporations with "good" reputation, and the best employees prefer to work for one of the "good" corporations (McBarnet, 2007).

This new society desires to change the classic economic guiding principle of profit maximization for the shareholders. This reformed market privileges businesses with long-term viability, ethical behaviour, and environmental responsibility.

Nonetheless, the paper of CSR beyond the law has only had a supplementary role. Government legislation should enforce CSR in order to prevent wicked corporate behaviour.

\subsection{CSR through the law}

Voluntarism in the application of the CSR makes that profit maximization determines whether CSR policies are applied. Because of that reason, some governments have chosen to introduce in the legislation, direct or indirectly, incentives to the adoption of corporate social responsible schemes (McBarnet, 2007).

"The United Kingdom, in its review of the company law in the 1990's, adopted to keep CSR a voluntary matter. At the same time, however, the UK government also introduced legislation which not only encouraged, but in practical terms necessitated, the adoption of CSR policies by major companies. The route was indirect, using disclosure as the tool, and indirect 
in another sense too, in that it was accomplished through legislation directed at investors in business corporations rather than at the business themselves". (McBarnet, 2007, p. 32)

The imposition of the adoption of internal codes of conducts, the disclosure of information and public reports of the corporation are the main ways used by the law to make corporations adopt CSR structures, in an indirect way.

Moreover, social pressure has been paramount to the regulation for CSR. The politicians, being the representatives of the society, have to develop social principles for which they were elected. Then, if the society desires a social responsible behaviour, in matters like human rights and environmental issues, from the corporations the law must reflect that and generate enforceable legal obligations (McBarnet, 2007).

Based on the created legal mechanisms, causes of action against corporations could be pursued. Then, causes of action may become a strong tool to control the corporate bad behaviour, used in NGO activism and private activism to stop corporate misbehaviour (McBarnet, 2007). Accordingly, the reputational damage of a legal process, after a breach of these principles, can cause competitive disadvantages to the corporation. This effect demonstrates that there is an interaction between CSR beyond and CSR trough the law (McBarnet, 2007).

CSR through the law is an expression of the difficulties in regulation. It is not possible to mandate to corporations all the changing CSR policies without creating a problem with economic efficiency. The big questions are "how much regulation is required?" and "to what extent should the "good" behaviour of corporations be guaranteed, without an economic distortion?" The answers to these queries would involve endless regulatory problems.

\subsection{CSR for the law}

In our globalized economy, some corporations have more resources and power than the countries where they are conducting business in. The law and the CSR are trying 
to face the rapid evolution of the markets and to impose a control on the abuse of the corporate power. "The issue of globalisation is real enough. While big business is transnational,
global institutions for governance of business remain poorly developed,
particularly when it comes to enforcement, and competition between different
jurisdictions allows business to play the game of regulatory arbitrage, moving
away from a high regulation area to a less demanding legal environment, or
achieving a more amendable legal environment where it is, through the threat
of such move." (McBarnet, 2007, p. 45)

Law is not enough when corporations create legal figures to avoid liability or press the government. For instance, some corporations take advantage of unregulated lobby while corporations are trying to maximize only their profits (McBarnet, 2007). In this context, a joint effort between the market forces, government, and social organizations is required to create limitations, impose rules of conduct, and apply them to those corporations that want to avoid their liability (McBarnet, 2007).

For Caro (2006), social capital promotes social activism in a society and compels the government to generate laws and impose sanctions. Social capital is one of the basics values to control the abuse of public and private power. It is especially important when corporations behave badly, or when businesses generate tricky ways to avoid the law.

"in short, social and legal means need not be seen as alternatives for furthering corporate responsibility, but as complementary controls in a new style of corporate accountability that involves both legal and ethical standards. [...] Both legal and social accountability have a role to play." (McBarnet, 2007, p. 55) 


\title{
Reputational Risk and CSR
}

Therefore, the reduction of reputational risk is one of the main ways to convince corporations to adopt CSR policies beyond the law. In the current markets, where social activism, shareholder activism, responsible investment, stakeholder perspective and media are variables that affect brand-oriented companies' competitiveness in the long-term, CSR policies beyond the law are an advantage.

In high competitive markets, there is an increasing pressure on directors to break the rules and obtain an advantage (Ingo, 2010). However,

\begin{abstract}
"Since maximizing the value of the firm is supposed to be the ultimate role of management, its job is to learn how to run the firm so that optimizes the longterm trade-offs between profits and external control It does no good plead unfair treatment - the task is for management to learn to live with it, and to make the most variables it can control.” (Ingo, 2010, p. 109)
\end{abstract}

\section{Reputation and Reputational Risk}

\subsection{Meaning of reputation}

It is essential start with a definition of reputation in order to define reputational risk. Reputation

may be defined as the opinion (more technically, a social evaluation) of the public toward a person, a group of people, or an organization. It is an important factor in many fields, such as [...] business [...]. In a business context, reputation helps drive the excess value of a business form and such metrics as the market-to-book-ratio. (Ingo, 2010, p. 105)

Reputation can also be understood as "the beliefs or opinions that are generally held about someone or something" (Ingo, 2010, p.). According to both definitions, 
reputation is then a subjective issue that involves the perception of a person who, in turn, is part of the society (Ingo, 2010). Perception is not reality.

In a corporation, two reputations coexist: (a) the reputation of the whole corporation, which is determined by the corporation's actions while they are conducting their business (Ingo, 2010), and (b) the reputation of the directors that can affect the whole organization "corporate behaviour, business ethics and the integrity of individual directors have become inextricably entwined as drivers of reputation. [...] ethical lapse can devastate a company's reputation and that behaviour is a critical component to how a company is perceived" (Ingo, 2010, p. 22).

The most relevant and concerning opinion is the one is held by stakeholders. From a stakeholder's perspective, reputation has another meaning: "Reputation is a collection of perceptions and beliefs, both past and present, which reside in the consciousness of an organization's stakeholders" (Ingo, 2010).

Stakeholders' perspective on reputation and the concept of social licence to operate have changed the way in which reputation used is formed. In the current markets, reputation depends on pressure groups (Ingo, 2010). Consequently, reputation is often at risk. To build a reputation takes years, but it can be destroyed in a second. Anyone in the corporation or anyone with whom the organization has business with can potentially damage the reputation (Ingo, 2010). Moreover, loss of reputation may be unfair.

Reputation is an intangible asset. Measuring intangible assets, to valuate a firm, is always a controversial, hard task. This job is particularly difficult when the intangible asset to be appraise is the firm's reputation; to estimate how much reputation loss affects a corporation is worse.

\subsection{Reputational risk}

In accordance with the previous discussion, reputational risk could be defined as follows: "Reputational risk comprises the risk of loss in the value of a firm's business 
franchise that extends beyond event-related accounting losses and is reflected in a decline in its share performance metrics" (Ingo, 2010, p. 105).

Even corporate directors do not have a precise and unified method to measure reputational risk. They just know that it exists and are aware of its devastating consequences. In fact, "a survey conducted in 2001 by the insurance company Aon, which polled the UK top 2000 private and public organisations, showed that 'loss of reputation' was seen as the greatest risk, followed by 'failure to change'" (Rayner, 2003, p. 21).

According to Ingo (2010), the most recognized sources of reputational risk are (a) the cumulative reputation of the firm, including its self-promoted ethical image, (b) economic performance-market share, profitability, and growth, (c) stakeholder interface-shareholders, employees, clients, and suppliers, and (d) legal interface-civil and criminal litigation and enforcement actions.

Reputational risk is related to administrative processes and, more exactly, to the decisions made by the board of directors. Based on short-term, medium-term or longterm perspectives, the board of directors may make decisions that could compromise the corporation responsibility. Further, high-profile companies and well-established, brand-oriented companies are the most affected by reputational risks (Ingo, 2010).

As said before, reputation is an opinion that depends on its holder. Therefore, reputational risk is determined by changes in beliefs and values of the society where the person and/or company are. Consequently, reputational risk is very vulnerable and unstable: "A single lie destroys a whole reputation of integrity" (Baltasar Gracian cited in Mulvey, 2008).

\subsection{Reputational risk and media revolution}

The informative revolution has changed the whole perspective about reputation. Currently, anyone or anything can be in the news around the world, regardless of how far the piece of new was originated (Rayner, 2003). 
The media look for news that generate an impact for the society. It is a market in itself: Countless agencies are competing for information. The agents in that market are aware of the fact that anything can be exploited. As a matter of fact, "the voracious media, ever quick to detect a chink in the corporate armour, will bay for blood if they spot a story that has potential appeal and could fill column inches over a period of weeks or months" (Rayner, 2003, p. 7).

Bad behaviour makes the news. Then, media constitute one of the main and more effective "watch dogs" of corporate policies, and one of the highest risks for the corporate image. Nowadays, the effects of media are infinite and daunting because, through the internet, their reports and information can be accessed anytime, anywhere. To make the situation worse, the media can change stakeholders' perspective suddenly, and completely damage the reputation of the company.

\subsection{Reputation, brand and advertising}

Firstly, it is important to make a distinction between corporate reputation and brand reputation. The difference is relevant when a corporation has more than one brand, and all of which are managed by the same corporation. For instance, "Procter \& Gamble will have an overall 'corporate reputation' to which its many individual brands contribute. Those diverse brands, such as Crest, Pampers, Olay, Prongles, Sunny Delight and Tampax, will each enjoy their own brand reputation" (Rayner, 2003, p. 10).

In that case, the reputational risk will depend on how close the image of a corporation is to its brands. A harm caused to one of the brands can affect the entire corporate reputation, especially, in cases of consumer protection. However, if the brand is not closely related to the corporation, the reputational harm would be less (Rayner, 2003).

Brand and advertising are closely related. To generate a brand is to build demand for a product in a competitive market; advertising is crucial to achieve it. The objective is inform to the public about a product or a company, generate a mental image, and, then, try to influence the public in acquiring the products of that company or to 
buy and specific thing (Dirksen \& Kroeger, 1986). Advertising "is a form of selling and it urges people to buy goods or services or to accept a point of view" (Dirksen \& Kroeger, 1986, p. 4).

According to Dirksen and Kroeger (1986), advertising has become paramount for a corporation since "in the business area over 90 percent agreed that advertising is essential to business and that the public places more confidence in advertised products than in unadvertised ones. Over 93 percent think that advertising speeds the development of markets for new products" (p. 17). For similar examples, see Lee and Johnson (2005).

Advertising can be direct or indirect. Direct advertising aims at making people have an immediate reaction to the publicity. Indirect or institutional advertising, which is the most relevant for reputation, attempts to create a favourable image of a brand or a corporation and change consumers' preferences "to increase the sales of a product (or service) or a specific brand owed by the manufacturer" (Dirksen \& Kroeger, 1986, p. 11). According to advertising theory, institutional advertising is intended to produce a good perception of the company (reputation) in stakeholders in order to increase business sales. In consequence, a good corporate reputation has a direct impact in the income for sale a product or a service.

Although the effectiveness of advertising depends on the characteristics of the market, corporations know that is necessary to invest in it and indirectly build a reputation in the market that differentiates them from the competitors.

Even advertising constitutes a high cost for a corporation, corporations are historically increasing their investments in advertising (see Lee \& Johnson, 2005). Furthermore, advertising is starting to include corporate management issues as an important part to create a corporate image.

"Today it is no longer enough for Burger King or McDonald's to come out with a new product and spend $\$ 75$ million on television commercials. Advertising plans must not only involve all the organization communications 
system but also the entire organization in total management of all brand contracts.” (Lee \& Johnson, 2005, p. 3)

This situation creates another source of reputational risk. As corporations, advertisements are subjected to reputational risk. Thus, corporate reputation and/or brand(s) reputation may be jeopardized.

Additionally, any bad corporate policy or behaviour that produces pressure groups' activism or any action from the government could spoil corporate advertising strategy and corporate image. In that case, a corporation will need to design other advertising strategies and campaigns. Then, it would mean more advertising expenses for the corporation. In summary, a bad reputation makes advertising prices rise and could make the corporation lose the money that it had invested in advertising.

\subsection{Reputation and the new activism}

\subsubsection{Shareholder activism}

Reputation can affect share prices of a company. For that reason, the investors are concerned with reputation. Reputation could determine whether the shares are a good or a bad investment.

A strong corporate reputation gives the corporation access to more investors. For example, it can reach entities that invest large sums in the securities markets, such as insurance companies, investment companies, pension funds, or trust departments. Organizations like this are designated institutional investors.

In fact, a big portion of invested capital is concentrated in institutional investors. Institutional investors have the legal duty to act solely in another party's interests, which is denominated a fiduciary duty. Accordingly, "institutional investors have always had a duty to secure value for the ultimate beneficiaries of the investmentpension schemes members, insurance policyholders and individual savers- by continuously monitoring the performance of the companies in their portfolio" 
(Rayner, 2003, p. 30). Because of these duties, institutional investors do not invest in a corporation with a bad reputation or bad market behaviour.

Similarly, shareholders are starting to be more concerned about corporate behaviour in the market and corporate reputation, and to act about it. Concisely, buying a share is making an investment in a corporation. Therefore, the shareholders, protecting their own money, worry more about how the corporation behaves and how its reputation evolves.

A bad corporate policy can represent important losses for shareholders in their investment and, hence, in their capital (Rayner, 2003). Consequently, some markets are experiencing an increase on shareholders' actions against corporations and directors. Because bad decisions affect a large number of shareholders, complaints and petitions are often filed in court as group i.e. class-action lawsuit. In general, shareholders seek legal or equitable remedies. They also improve corporate governance (Rayner, 2003).

"As well as abstaining or voting against resolutions at company annual general meetings and voting against the re-election of directors, disgruntled investors are now often prepared to voice their concerns to the media though the publication of league tables, sharing previously confidential research, and through overtly critical comments on individual companies and directors. [...] the major investors cannot risk being accused of being sleep on the watch, or of dilatoriness in safeguarding the investments entrusted to them." (Rayner, 2003, p. 32)

This process has introduced a new variable into the decision of a shareholder to invest: to make a responsible investment. As directors of corporations are taking distance from focusing only on profit maximization, the investors are also concerned not only with the dividends of their investment but also with their own reputation. In consequence, some of them often look for a social responsible investment which "combines investors' financial objectives with their commitment to social concerns, such as social justices, human rights, economic development, peace or healthy environment" (Rayner, 2003, p. 33). 


\subsubsection{Other pressure groups}

In some cases, the activism of NGOs and of other pressure groups has changed the political agenda. Then, pressure groups are important actors who can control corporate behaviour. As the media, pressure groups need a big scandal in order to consolidate their own image (Rayner, 2003).

Environmental, or green, groups have made a huge change, for instance. A few years ago, environmental harm was almost unperceived, and corporations treated it as a negative externality of production (Rayner, 2003). After the consolidation of green groups, it is unlikely that a corporation can harm the environment without being exposed. Because of pressure of green groups, some of the agendas of the government have changed in order to prevent or sanction those corporate abuses (Rayner, 2003).

"Herein lies both a perilous threat and a fertile opportunity: inciting the wrath of pressure groups can cause irreparable reputational damage. In contrast, working in collaboration with an NGO could convert your most vociferous critic into your most ardent fan and goodwill ambassador image." (Rayner, 2003, p. 36)

Thus, the struggle between the NGO's and transnational companies can be changed to a mutual assistant relationship to develop and apply CSR principles (Mulvey, 2008).

Another pressure group that can strongly influence public opinion and/or policy is consumer associations. When these organizations work jointly, they can generate enough pressure as to harm corporate reputation.

\section{Reputational risk and transaction cost}

Whenever a company makes an agreement in uncertain situations, it incurs higher transaction costs (Burke, 1999). Reputational risk increases uncertainty; in turn, it rises transaction costs. These costs are derived from the company's relation with its 
clients, investors, workers and business partners. For instance, a company's reputation can influence customer and investor preference for products or companies. Similarly, a bad corporate reputation can cause talent flight, more difficulty to obtain financial capital, and higher costs of any contract (Rayner, 2003). The more reputational damage,

"(1) the greater the likelihood that the firm will encounter exploitable conflicts of interest and reputational risk exposure; (2) the higher will be the potential agency cost facing its clients; and (3) the more difficult and costly will be the safeguards necessary to protect the value of the franchise." (Ingo, 2010, p. 115)

A clear example of the relationship between reputational risk and transaction cost can be found in the financial crisis 2008 in the United States. The American financial sector (banks, investment funds, loan entities, insurance companies and real estate) suffered an unprecedented reputational damage caused by their bad politics and behaviour, which where the basis of the financial crisis (Ingo, 2010).

The industry was guilty of poor risk management with serious overreliance on flawed models, inadequate stress-testing of portfolios, recurring conflicts of interest, and lack of common sense, as well as irrational compensation practices not linked to long-term profitability-with a growing perception by the public of "clever crooks and greedy fools". (Ingo, 2010, p. 103)

Clients reacted to financial companies' bad behaviour. After the financial crisis, the clients started to withdraw their deposits from banks and main financial institutions. In fact, they were losing their clients because of their bad behaviour (Ingo, 2010). As a consequence of all this, the financial sector suffered a reputational damage that increased its transaction cost.

Reputation is an essential asset for the financial sector because these entities manage other persons' money. Clients and investors are now really sensitive and concerned about trusting their money to those businesses (Ingo, 2010). Particularly, image 
becomes paramount when the corporation is brand-oriented. Hence, investors, clients and workers think twice about making business with them nowadays.

Nonetheless, reputational damage, as a consequence of bad corporate policies, does not only transpire in the financial sector. Bad policies and reputational damage increase transaction cost in other sectors. However, all that would have been avoided by applying CSR principles. For example, Nike suffered from a reputational damage because of bad labour policies adopted by one of its outsourcings. In a similar fashion, General Motors is undergoing reputational damages because its bad policies that decreased car safety to maximize profits, which were sanctioned by the court. Because of other unethical policies, Enron was subjected to a huge reputational damage that, eventually, led it to the bankruptcy. For an analysis of Nike, Enron, and Shell cases see McBarnet (2007).

The origin of these malpractices could to be a lack of proper corporate governance. Any of the corporations mentioned applied corporate social responsible principles. Instead, they privileged profit maximization in the short-term. By the same token, bad corporate policies and damages to corporate reputation have similar effects (e.g. increase in transaction costs), regardless of the economic sector in which businesses are conducted.

\section{Reputational risk and regulation}

Laws and regulation must reflect those behaviours that are accepted or prohibited, depending on the values of the society. These basic values must be respected by all the members of the society, including corporations, and be modified according to the changes and evolution of the society. A violation of those principles will cause an action against any person. Therefore, there could be a strong regulation of corporate behaviours (McBarnet, 2007). Indeed, "the interesting point about these legislative and regulatory actions [...] is that they were introduced because US business was patently incapable of a standard of self-regulation that would satisfy key stakeholders" (Rayner, 2003, p. 26). 
An example of the relation between reputational risk and regulation can be drawn from the financial crisis of 2008 in the United States. Misconstruing CSR principles, some corporations were prone to argue and opt for a self-regulatory system and for market discipline. In this fashion, they attempted to avoid or to prevent government regulation. However, that plan only works until another major transgression [occurs], and the constraint system reacts and creates a spate of new regulations (McBarnet, 2007).

After a financial crisis, for example, government tends to regulate, and sometimes overregulate, the financial sector. It knows the system and it is aware that it has to protect persons from abuses during the financial shock (McBarnet, 2007).

In conclusion, when corporations violate the laws or struggle with the government, reputational losses in the corporations are generated. Furthermore, it causes "the build-up of adverse opinion in the media, the formation of special-interest lobbies and pressure groups, and the general tide of public opinion with respect to one or another aspect of market conduct, can be reputationally debilitating" (McBarnet, 2007, p. 108).

Additionally, after a reputational loss, causes of action against the corporation are raised by pressure groups. Political, civil or criminal actions, from the corporate breach of conduct, could eventually increase transaction costs and bring about unfavourable regulation for corporations.

\section{Reputation harm}

A way to discover the amount of the losses produced by an event that harms reputation is "to estimate the overall market value loss of the firm to a reputationalsensitive event, and then deduct the monetary losses" (McBarnet, 2007, p. 111).

JP Morgan's involvement in a banking crisis in Spain can exemplify how a reputational-sensitive event can produce a negative effect in share prices. In 1993, JP Morgan made the first investment of its new banking fund, Corsair Partnership, 
in Banco Español de Crédito, S.A. (Banesto) (Ingo, 2009). JP Morgan also became Banesto's most important financial and businesss advisor (Ingo, 2009). Citing mismanagement and reckless lending, the Governor of the Bank of Spain took control of Banesco on December 28 of 1993 (Ingo, 2009).

According to McBarnet (2007), when the Bank of Spain took control over Banesco, JP Morgan's reputation was affected. This event raised questions in the market about (a) the ability of JP Morgan to advice their clients effectively, (b) the ability of JP Morgan in organizing and manage equity funds, (c) JP Morgan's proper risk evaluation and assessment, (d) JP Morgan's monitoring and economic operations, and (e) a possible conflict of interest or lack of objectivity in JP Morgan's investments.

Consequently, JP Morgan's share prices decrease when the Bank of Spain took control over Banesco (McBarnet, 2007). Additionally, "a cumulative loss of 10 per cent of the shareholder equity value is apparent 50 days after the announcement translates into a loss in JP Morgan market capitalization of approximately $\$ 1.5$ billion versus a maximum direct loss of only $\$ 10$ million from Banesco failure" (McBarnet, 2007, p. 113).

This impressive loss produced by the reputational harm was not expected. However, it demonstrates how the reputational damage can be worse in terms of magnitude than the expected losses. Similarly, in the study conducted in 2006 by Karpof, Lee, and Martin (cited McBarnet, 2007), it was discovered that the reputational losses are quite bigger than other kinds of monetary sanctions, such as fines, class-actions settlements, and accounting write-off.

Moreover, the factors that Karpof, Lee, and Martin (cited McBarnet, 2007) found to cause reputational damage were strongly related to bad corporate governance policies and, more precisely, to a lack of consideration of stakeholders' perspective. Corporations failed to apply corporate social responsible principles.

However, the existing economic models (referring to the neo-classic model and its advances) have a problem: they do not distinguish the overall market value loss of the company from loss related only to reputational damage (McBarnet, 2007). 
In summary, although the exact value of the reputational risk is hard to ascertain, the corporate directors are aware of the fact that it is such a significant amount that it can determine business viability in the long-term.

\section{ConClusion}

Contemporary society, where corporations are conducting business, has introduced new social requirements to the markets. In our current world, being a successful business is not only a matter of profits maximization or monetary indicators. A prosperous, forward-looking business needs to take into account stakeholders' perspective, social needs, responsible ways of production, and its sources of reputational risk. Those four factors can differentiate the company in the marketplace in order to beat its competition or can cause the company's defeat by its competitors.

Corporate social responsibility and reputational risk are closely related. As a matter of fact, reputational risk plays a significant role in CSR beyond the law as a powerful tool in the market. "Management and boards of financial intermediaries must be convinced that a good defence is as important as good offense in determining sustainable competitive performance" (McBarnet, 2007, p. 117).

Therefore, adopting corporate social responsible policies would be the way to reduce, or even eliminate, reputational risks in a global informatics context, where different activist groups and governments learn instantly about corporate behaviour. Nonetheless, reputational risk is only a supplementary instrument that cannot substitute regulations and governmental action.

Summarizing, CSR has become a competitive advantage that can (a) reduce transaction cost of the company by reducing its reputational risk, (b) maintain and increase share prices, (d) protect company's investments in advertising, and (d) determine business viability in the medium-term and long-term. 


\section{REFERENCIAS}

Armour, J., Hansmaan, H., \& Kraakman, R. (2009). What is a corporation? In Kraakman, J. Armour, P. Davies, L. Enriques, H. Hansmaan, G. Hertig, K. Hopt, H. Kanda \& E. Rock (Eds.), The anatomy of corporate law: A comparative and functional approach (2nd edition, pp. 5-16). Oxford: Oxford University Press.

Bagwell, K. (2001). The economics of advertising. Northampton, MA: Edward Elgar Publishing.

Bakan, J., (2004). The Externalising Machine. In J. Bakan (Ed.), The corporation: The pathological pursuit of profit and power (pp. 60-76). New York, NY: Free Press.

Burke, T. (1998). Risks and reputations: The economics of transaction costs. Corporate Communications: An International Journal, 3(1), pp.5-10.

Caro L. V. (2006). El capital social en Colombia: Teorías, estrategias y prácticas [Social Capital in Colombia: Theories, strategies and practices]. Bogotá, Colombia: Contraloría General de la República.

Dirksen, C. J. \& Kroeger, A. (1986). Advertising principles and problems (4th ed.). Homewood, Illinois: Richard D. Irwin Inc.

Friedman, M. (1970, September 13th). The Social Responsibility of Business is to Increase Its Profits. New York Times Magazine, (pp. 1-4)

Ingo, W. (2009). Reputational Risk and Conflicts of Interest in Banking and Finance: The Evidence So Far. In A. Aronson, H. Parmet, \& R. Thornton (Eds.), Variations in Economic Analysis (pp.75-97). Retrieved from http://link.springer.com.ezproxy.unal.edu.co/ chapter/10.1007/978-1-4419-1182-7_8

Ingo, W. (2010). Reputational Risk. In J. Boatright (Ed.), Finance Ethics: Critical Issues in Theory and Practice (pp. 103-123). Hoboken, NJ: John Wiley \& Sons Ltd. 
Jones, J. P. (1998). How advertising works: The role of research. Thousand Oaks, California: SAGE publications.

Karnani, A. (2011). Doing Well by Doing Good: The Grand Illusion. California Management Review, 53(2), 69-86.

Lee, M. \& Johnson, C. (2005). Principles of advertising: A global perspective (2nd edition). New York, NY: The Haworth Press, Inc.

McBarnet, D. (2007). Corporate social responsibility beyond law, through law, for law: The new corporate accountability. In D. McBarnet, A. Voiculescu and T. Campbell (Eds.), The new corporate accountability: Corporate social responsibility and the law (pp. 9 -33) Cambridge: Cambridge University Press.

Mele, D. (2008). Corporate social responsibility theories. In A. Crane, A. McWilliams, D. Matten, J. Moon \& D. S. Siegel (Eds.), The Oxford handbook of corporate social responsibility (pp. 47-82). Oxford: Oxford University Press.

Mulvey, P. (2008). Reputation really matters: How to guard your corporate image. Carlton North, Victoria, Australia: Monterrey Press.

Percy, L. (2008). Strategic integrated marketing communications theory and practice. Oxford: Butterworth-Heinemann.

Rayner, J. (2003). Managing reputational risk: Curbing threats, leveraging opportunities. Chichester, England: John Wiley \& Sons Ltd.

Tomasic R., Bottomley S. \& McQueen R. (2002). Corporate Governance: Structures and Issues. In S. Bottomley, R. Tomasic \& R. McQueen, Corporations Law in Australia (2nd Ed., pp. 262-291). Sydney, Australia: Federation Press. 
